\title{
12 The Influence of Historical and Institutional Legacies on Present-Day Social Enterprises in CEE Countries
}

\author{
Lessons From Poland, Hungary, \\ the Czech Republic and Croatia
}

\author{
Anna Ciepielewska-Kowalik, Davorka \\ Vidović, Julianna Kiss, László Hubai, \\ Katerina Legnerová and Marie Dohnalová
}

\section{Introduction}

In Poland, Hungary, the Czech Republic and Croatia, social enterprises are not simply a result of the socio-political transformation that took place in the 1990s and 2000s; or has their emergence been influenced only by EU integration. Current social enterprises are, in fact, products of a history of these countries dating back to the 19th century, when cooperatives, foundations and associations tried to meet social needs linked to the industrialisation process. This historical background is presented in the first section of this chapter. The following sections discuss the current situation of social enterprise (SE) in the four countries under consideration: Section 2 analyses the institutional background within which social enterprises emerged and operate, while Section 3 focuses on their ecosystem. A mapping of the SE phenomenon is then provided in Section 4, before comparative findings are presented in Section 5.

\section{Historical Background: Pre-Socialist and Socialist Period}

Some traditions that have shaped social enterprises derived from voluntary organisations have existed in Poland, Hungary, the Czech Republic and Croatia since the Middle Ages. Reference can be made to a tradition of charity and philanthropy fostered by the Catholic Church and which is shared by all four countries (Leś et al. 1999; Frič et al. 1999; Bartal 2005; Zrinščak 2008). Other traditions are those linked to foundations established by rich individuals (Poland, Croatia, Hungary); to programmes implemented by some municipalities and urban communities (Poland, 
Czech Republic); to mutual-aid associations and guilds (Hungary, Croatia); and finally, to the cooperative sector, which emerged in these countries in the context of an early industrialisation, in the second half of the 19th century.

In the four countries under consideration, in the interwar period, a turbulent political environment determined the role of the non-profit sector (i.e. foundations, associations and similar social organisations) (Leś 2001; Bartal 2005): the number of associations increased, and they strongly supplemented public authorities in providing social services for vulnerable groups. They were connected to cultural, political and economic issues, mutual assistance and professional-interest representation. In the same period, the cooperative movement also experienced an impressive growth, both in terms of expanding into new fields and in terms of number of newly created entities. As a result, the interwar period is referred to as the "golden years" of cooperatives in the Czech Republic (Hunčová 2004; Dohnalová et al. 2016), and this could also very well apply to Poland, Hungary and Croatia. According to some records (Vidović 2012; based on Žimbrek 2008), right before World War II, there were around 2,500 cooperatives in Croatia, totalling 460,000 members.

After World War II and the related turmoil, the political orders that were established in the four countries dramatically changed the situation of the non-profit and cooperative sectors for more than 40 years. However, these four decades were not homogenous in terms of real possibilities for associations and foundations. The most severe period was the time directly after the establishment of the communist order, in the late 1940s and the 1950s. In Poland, Hungary and the Czech Republic (Czechoslovakia at that time), the communist authorities undertook various actions to deprive associations and foundations of their autonomy, one of which was the institutional elimination of particular legal types, such as foundations, which become prohibited in Poland in 1952, and seven years later in Hungary. In Croatia (which was part of Yugoslavia at the time), where communist authorities declared all types of civic organisations to be "bourgeois entities", both foundations and citizens' associations were abolished. In Hungary, Poland and Czechoslovakia, communist authorities created state-sponsored and state-controlled organisations, referred to as "(mass) social organisations". These were born from the amalgamation of previously independent foundations and associations and were controlled by the Communist Party.

Over the following years, the situation of existing grassroots initiatives was volatile; it depended on the political situation. The political opening in the Czechoslovak Republic (in the late 1960s), Poland (in the late 1970s) and Hungary (in the 1980s), as well as the introduction of the "socialist self-management" model in Croatia (starting in the 1950s, and subsequently followed by the creation of particular legal frameworks by the Constitution of 1974), brought about a slight liberalisation. In 
Poland and Hungary, the partial toleration of grassroots initiatives was also a kind of "bargaining chip" used by communist authorities to ease possible social resistance. As a result, many organisations meeting social needs and engaged in human rights activities emerged. On the other hand, drastic political events, such as the declaration of martial law in Poland (1981) or the military invasion of the Czechoslovak Republic by the Warsaw Pact countries (1968) de-legalised most of the civic organisations and forced them to go underground. One should also remember that, at that time, in Poland and Croatia, the Church (mainly through Caritas) was an active social-service provider.

The first legal recognition of the non-profit sector, which resulted in its revival, took place in the 1980s and early 1990s in all of the countries analysed. In Croatia, the Act on Social Organisations and Citizens' Associations was adopted in 1982. Later, this legislation enabled the emergence of associations and political parties-a development which, in turn, constituted an entrance into a multiparty democratic system. In Poland, such a transition to the democratic system was achieved by bringing back foundations into the institutional map, in 1984, and introducing a new legal framework for associations, in 1989. In Hungary, the Civil Code restored the legal form of foundation in 1987, while the new law on associations was adopted in 1989, after the regime change. The Czech Republic introduced a new legal framework for associations just after the collapse of communism, in 1990.

As for cooperatives, they remained fundamental economic institutions throughout the communist period, and they even monopolised some branches under centrally planned economies. But they also became instruments of the communist regime; membership in cooperatives was compulsory, and they were entities controlled by the state.

\section{Institutional Background for SE Emergence in Post-Socialist Regimes After 1989-1990}

As regards Poland, Hungary and the Czech Republic, some initial steps towards a gradual recognition of present-day social enterprises had been taken by the mid-1990s. Not only as a result of regime changes that resulted in democratisation and a rise of freedom, but also brought about growing social needs, an unprecedented rise in the number of civil-society/ non-profit organisations was observed. By the mid-1990s, there were 47,000 non-profit organisations in Poland (Mansfeldová et al. 2004), 40,000 in Hungary (Bényei et al. 2007) and 26,814 in the Czech Republic (Nadace Neziskovky.cz 2018). In Croatia, though, democratisation was delayed through the 1990s, due to the specificities of the transition in this country (violent breakup of Yugoslavia, war for independence and nation-state building process). Associations, for example, were regulated until 1997 by the aforementioned Act on Social Organisations 
and Citizens' Associations, adopted in 1982, during socialism, which was not in line with democratic principles; this is revealing of how nonsupportive and suspicious the regime remained towards civil society during the 1990s.

The period of the 1990s was marked by the significant role played by foreign funding in all the countries analysed. Analysis of available data reveals that international donor support represented between $4.1 \%$ and $8.4 \%$ of the total budget of non-profit organisations in Hungary (Nagy and Nizák 2009); this figure even reached $16 \%$ in the case of Poland (CIVICUS 1997). Besides monetary assistance, foreign donors also provided know-how support through numerous Western-based organisations.

In Poland, the Czech Republic and Hungary, the second half of the 1990s and the early 2000s were characterised by further institutionalisation of non-profit organisations. This was achieved by the introduction of different mechanisms, including the creation of new statuses (publicbenefit organisations) for organisations entitled to public funding (Poland and Hungary); legal frameworks regulating mutual relations between public authorities and non-profit organisations; and new legal forms, such as those of public-benefit company (later transformed to non-profit company) in Hungary and of social and professional (re-)integration organisations for different categories of socially disadvantaged groups (usually regulated by labour and/or social employment acts) in Poland.

As for Croatia, things changed and accelerated from 2000 onwards, with the change to a more democratic regime. With the new 2001 Association Act, non-profit organisations started receiving more supportive treatment. The government also established a set of institutions to cooperate with civil society, and in 2005 , it adopted the first "National strategy for the creation of an enabling environment for civil society development 2006-2011" (Government of the Republic of Croatia 2006), which was the first document mentioning social entrepreneurship.

In 2004, Poland, Hungary and the Czech Republic became members of the EU; this year should be regarded as the beginning, in these countries, of the policy recognition of social enterprise per se. This was done through the formal introduction of new legal forms (such as that of social cooperative in Poland and Hungary, in 2006), on the one hand, and by favouring the evolution of traditional non-profit organisations towards a more entrepreneurial position, supporting their transformation into the so-called "entrepreneurial non-profit organisations", on the other hand. The EU-funded projects carried out in the framework of the European Social Fund (ESF) and the European Regional Development Fund (ERDF) created an unprecedented flow of funds, which stimulated the growth and a greater recognition of social enterprises.

Unlike non-profit organisations, after 1989, traditional cooperatives experienced a sharp decrease in terms of numbers in all the countries 
under consideration, and they received almost no recognition by political elites and societies. They were regarded as relicts of the communist regime, and thus seen as neither autonomous nor effective entities (Leś 2004; Hunčová 2004; Dohnalová 2013; Kovách 2012; G. Fekete et al. 2017; Ciepielewska-Kowalik 2015; European Commission 2016; European Commission 2020; Vidović 2012; Pejnović et al. 2016). Moreover, in Poland, the Czech Republic and Croatia, this negative trend was reinforced by unfavourable legal frameworks (adopted, respectively, in 1990, 1992 and 1995). For instance, in Poland, according to the 1990 Act on Cooperatives, all cooperatives' alliances, as relicts of the previous system, were closed down by the end of 1990 . Those that were re-established under the new legal framework were never returned the estate of their predecessors. Other regulations deprived cooperatives of their social character, either by treating cooperatives' estate as private estate of their members, or by making these organisations give up the pursuit of social aims by pushing them into sharp competition with private for-profit companies (Cioch 2011). Only recently have traditional cooperatives started regaining more political and social interest in the countries studied.

Social cooperatives, which have been self-recognised as social enterprises per se in Poland and legally recognised in Hungary since 2006, and in Croatia since 2011, are experiencing a different path of development. In Poland and Hungary, they are receiving more political interest, and they benefit from wider acceptance from the general public than traditional cooperatives. Qua new-wave social enterprises addressing welfarestate challenges, particularly in the field of social and professional (re-) integration of disadvantaged groups, they are entitled to strong financial support from public authorities, including EU funds. This has resulted in a very dynamic growth of social cooperatives, in particular in Poland and Hungary. In Croatia, by contrast, these organisations were not particularly valued by the political actors, or were they granted particular incentives, and as a result their growth was more limited (Vidović and Rakin 2017).

Finally, market liberalisation and the introduction of private ownership have also resulted in a significant growth of small and medium-sized enterprises: by the beginning of the 2000s, SMEs represented an overwhelming majority of registered enterprises in all the countries studied (for example, in Croatia, in 2001, 99\% of enterprises were SMEs, and employment in small enterprises, which accounted only for $9 \%$ of total employment in 1990, reached $34 \%$ in 2001 , according to Singer and Lauc 2004). Given the constraints that drive NPOs to carry out business activities, it can reasonably be considered that some of these SMEs might be social enterprises. It is also often the case that social enterprises operate as a hybrid form of two or more legal entities (for instance, a nonprofit can establish a trade-arm company; see G. Fekete et al. 2017 and European Commission 2019b). By resorting to such legal arrangements, 
these organisations try to overcome some disadvantages of the existing legislation, connected to the various legal forms available to them. And even though these social enterprises are not legally obliged to comply with the non-distribution constraint, they often do so on a voluntary basis.

\section{Current SE Ecosystem}

In recent years, the ecosystem of social enterprises has developed significantly in all the countries studied. This development can be examined at several levels: legal and policy reforms recognising the sector, changing relationships with the public-welfare system, as well as fiscal and financial mechanisms supporting social enterprises.

\subsection{Legal and Political Recognition}

In the countries studied, different approaches can be distinguished regarding the legal recognition of social enterprises. Some approaches or instruments are common to the four countries, while others exist only in some of them.

Common instruments include the adoption of specific policy strategies recognising social enterprises in the broader context of the social economy or social entrepreneurship; the delegation of responsibility for issues linked to the social economy/social enterprises among central or regional/local structures; ${ }^{1}$ and the legal introduction of particular types of social enterprise (mainly social cooperatives).

Another feature that is common to all the countries under consideration is the fact that none of them has yet introduced a legal framework specific to social enterprise. As a result, social enterprises operate under various legal forms, and they are regulated by different legal frameworks, specific to these different legal forms. This situation may be explained by the fact that a common legal definition of social enterprise has not yet been agreed upon in these countries.

Other approaches and instruments, as just mentioned, exist only in some of the countries under consideration.

An example of an instrument used only in some countries is provided by the specific governmental structures/units focused on promoting the social economy/social enterprises that have been created in Poland and Croatia.

Secondly, in some countries, social enterprises can be officially recognised as such by applying for an "SE status"; all entities complying with a defined set of criteria can obtain this status, regardless of their legal and organisational form. Enterprises with this special status become eligible for state funding. This approach has already been proposed in Croatia (in the Strategy for the Development of Social Entrepreneurship, in 
2015), and in Hungary (from 2017 onwards), where an SE status functions as a "label" for organisations. Compliance with the set of criteria provides certain advantages, such as extra points in ongoing funding programmes (European Commission 2019b). Poland (in 2014 and 2018) and the Czech Republic (in 2017) have prepared draft acts with such an approach, thus moving towards the adoption of a similar solution.

Two of the four countries have designed a specific legal framework for activities with a social focus, carried out by organisations with different legal forms: such an approach was implemented by public authorities through the introduction of the public-benefit status for organisations providing public-benefit services in Hungary (in the late 1990s) and Poland (in the early 2000s).

Some of these four countries also decided to regulate only particular types of social enterprise. This is for example the case for social cooperatives: Poland and Hungary adopted regulations for social cooperatives in 2006, and the Czech Republic did so in 2014. Croatian legislation, by contrast, recognised the social cooperative as a specific type of cooperative in 2011 but without introducing any particular regulation or incentive.

Finally, a fifth approach that has been implemented only in some countries corresponds to the formal recognition of work-integration social enterprises (WISEs). This is what happened in the Czech Republic. In Croatia, the model of sheltered workshops had been formally recognised since the era of socialism, but only recently have other social enterprises started to self-recognise themselves as WISEs too.

\subsection{Relations Between Social Enterprises and Public-Welfare Systems}

None of the analysed country has yet defined the role of social enterprises in its public-welfare system. However, comparative analyses have revealed that different types of relations between social enterprises and public-welfare systems co-exist.

The first type of relations corresponds to the conflation of social enterprises with WISEs; in such perspective, social enterprises exist as entities taking part in the implementation of active social policy rather than as autonomous market players. The existence of relations of this type can be accounted for by the activities undertaken by pioneering social enterprises, which provided work-integration services to groups threatened by social exclusion. This happened with a strong support by EU funds but with no clear vision of social enterprises' role at the country level. This approach has been maintained over the years and is now reflected in some countries' embryonic legal frameworks for social enterprises. National legislations are conflating the notion of social enterprise with that of WISE either in a direct way, by defining social enterprise through 
the prism of the provision of reintegration/pro-employment services (in Poland and the Czech Republic), or indirectly, by relating state funding to various forms of employment of vulnerable groups (in Croatia and Hungary). Worth noting is the fact that, despite a strong tendency to conflate social enterprises with WISEs, the latter have been formally recognised only in the Czech Republic.

In the countries studied, a second type of relations that was identified acknowledges the role of social enterprises in undertaking activities that are complementary to the ones carried out by the public sector, such as social services provision. It means that social enterprises are perceived as a kind of "supplementary entities" rather than as fully autonomous and equal partners, providing different kinds of services. This type of relation appears to be linked to the fact that the concerned social enterprises have only limited economic potential, and suffer from a lack of political recognition and public support. In the Croatian case, these limiting factors were moreover accompanied by an ambiguity towards civil society and a lack of trust-or, in other words, by a low level of social capital, which was inherited from the 1990s and continued to persist in the general public (Štulhofer 2004).

Social cooperatives, which have awakened much political interest since the EU integration, seem to be in a better position and are now expanding into new domains, including child care, community services/development, building and reconstruction, sport and tourism. This is clearly visible in Poland, but not as apparent in the other three countries under consideration, where the role of social enterprises in public-welfare systems is not yet well developed.

\subsection{Financing and Fiscal Frameworks}

A comprehensive public financial support system, which could effectively foster social enterprise, has not yet been developed in any of the four countries studied. In terms of fiscal benefits, some social enterprises benefit from different types of incentives related to their legal type, including tax privileges and exemptions, and reduced social-security contributions. In Poland and the Czech Republic, support measures recognise social enterprises within the broader context of the social economy, while Hungary and Croatia recently adopted funding programmes, mostly within the framework of EU-funded programmes, that target social enterprise specifically.

In all the countries studied, support measures target organisations providing specific types of services, particularly in the field of professional and social integration of disabled persons. All types of enterprises employing persons from specified disadvantaged groups, in particular persons with disabilities, benefit from public subsidies, reimbursements and reduced social-security contributions. 
Hungary (in 1997) and Poland (in 2003) introduced a system of financial support for initiatives with different legal types having the status of public-benefit organisations (mostly associations, foundations and social cooperatives), allowing these organisations to benefit from tax exemptions. Certain legal forms performing public-benefit activities can also receive funds from taxpayers in the form of a percentage of their taxes which they allocate to the organisation of their choice (this system is referred to as the " $1 \%$ scheme"). In Croatia, natural or legal persons donating to non-profits also benefit from a tax reduction, up to $2 \%$ of their annual income; however, associations involved in an economic activity become obliged to pay taxes as regular companies.

In all the countries studied, social enterprises' access to finance offered by banks is limited. Traditional banks are not interested in supporting social enterprise, as the latter is perceived as a low-profit and high-risk sector. In Hungary and Croatia, some commercial banks, such as Erste Bank and Zaba, sporadically fund some small-scale projects with a "social impact". Only recently did Erste Bank introduce its social banking programme for Southern and Eastern European countries, which aims to support both unemployed individuals in becoming entrepreneurs and social enterprises. Socially oriented banks or ethical banks have not yet been established in Poland and the Czech Republic, while in the other two countries studied, such banks' activity is still in an embryonic stage: in Hungary, MagNet Bank has developed initiatives and programmes specifically tailored for civil-society organisations, while in Croatia, the Cooperative for Ethical Financing, established in 2014, unsuccessfully tried to establish the first ethical bank (the project was rejected by the Croatian National Bank in 2018).

\section{Mapping Social Enterprises}

Analysing the size of the SE sector from a comparative perspective is a very challenging exercise, as formal recognition of social enterprises is still in statu nascendi in the countries studied. Moreover, the SE sector is not homogeneous in terms of the legal forms under which social enterprises operate in the four countries. Social enterprises can operate as associations, foundations or cooperatives (including as social cooperatives) in all the countries studied. The legal form of non-profit company is recognised in three of the four countries (namely Poland, the Czech Republic and Hungary). Other legal forms exist only in one of the four countries: this is the case of professional-activity establishments (zaktady aktywności zawodowej) in Poland, institutions (ustanova) in Croatia and institutes (ústav) in the Czech Republic. Another reason which makes it difficult to provide precise numbers about the SE sector is linked to the poor quality of data-collection mechanisms about social enterprise at country level. 
For these reasons, any estimate of SE-related figures across the countries studied should be treated as preliminary; however, despite these limitations, our analysis provides some overall overview of the most important trends in the SE sector in Poland, Hungary, the Czech Republic and Croatia.

Analysis reveals that the most common form for social enterprises across the four countries studied is that of entrepreneurial non-profit organisation (ENPO). ${ }^{2}$ There were 27,600 ENPOs registered in Poland in 2016 (European Commission 2020); in Hungary, in the same year, 12,875 non-profit organisations had a significant level of business revenue (European Commission 2019b). This strong representation of ENPOs can be accounted for by the historical development of the nonprofit sector, and especially by its long-standing tradition, whose roots can be traced back to the period before World War II (even though this sector's development was discontinued by the communist regime), and by the incredible increase in the number of NPOs that has occurred following the democratic changes, from the late 1980s onwards in Poland, Hungary and the Czech Republic, and since 1990 in Croatia.

Interestingly, in Croatia, the establishment of companies or cooperatives by associations is also common. The main reasons for this are the legal requirements that make it complicated for associations not only to carry out economic activities, but also, to an even larger extent, the predominant mindset in the country, and in particular among public administration, according to which non-profits cannot generate income in the market (European Commission 2019a). Also noteworthy is the fact that, in Hungary, unlike in the other three countries studied, nonprofit companies are important in terms of both numbers and economic weight, despite the absence of a favourable legal framework; this can be accounted for by the close historical connection of many Hungarian nonprofit companies to the public sector, which has given them priority over grassroots associations and foundations in the allocation of public funds (Bocz 2009). Poland, unlike Hungary, enacted some favourable legislative frameworks for non-profit companies.

Cooperatives are less numerous among social enterprises. However, the introduction of the legal form of social cooperative and the funding opportunities targeting them strengthen the role of cooperatives in the SE sector. Over the last years, a gradual and steady increase in the number of social cooperatives has taken place; this evolution is clearly visible in Poland and Hungary, ${ }^{3}$ although much less significant in Croatia.

\section{Comparative Findings}

When comparing the four post-socialist countries included in this study, some notably important trends should be highlighted. Indeed, all the countries considered have followed very similar paths of SE development, 
although with some time lag, with the post-Soviet countries somewhat "preceding" the post-Yugoslav societies. In this section, we analyse both elements of discontinuity and elements of continuity across the presocialist, socialist and post-socialist periods, and convergences and divergences among the analysed countries.

\subsection{Continuity and Discontinuity}

There are a few practices and values that may be identified as important elements of continuity of SE-related traditions.

This particularly includes a wide spectrum of bottom-up civic activities that existed throughout each of the mentioned periods, even during socialism, even though voluntary foundations and associations established by citizens were then abolished or controlled by the state. These activities are also linked to a strong history of volunteering and solidarity movements, which had the power to encourage citizens to help others and devote time to contribute to society. Those practices reflect that fact that social entrepreneurship, as a practice and as a mind-set, is deeply rooted in tradition and historical forms, values, organisations and activities of post-socialist European societies. Furthermore, it reveals that social entrepreneurship and social enterprise did not emerge only with the democratic transition or EU integration, but also have their own inherited origins, which go further back in the history of the considered countries.

Social enterprises' development path is also marked by some striking discontinuities between the various periods of these countries' history.

The first type of major discontinuities relates to church-based and other religious organisations. These were among the most important actors in the field of social services provision during the pre-socialist period. Under the socialist regime, those organisations were abandoned. Overall, the role of the church was revitalised with the transition, and these organisations became again very influential in most of the countries analysed, but their role in social services provision and in the SE sector has not bloomed proportionally to their regained influence in society in most of the countries analysed. As a result, only a small share of social enterprises can be identified today as religious/churched-based organisations in the four countries analysed.

The second most striking discontinuity relates to the role and treatment of cooperatives. In the pre-socialist period, they were quite developed in the four countries considered, and they played a key role in the socioeconomic development of local communities. The misuse and instrumentalisation of cooperatives that occurred under the socialist regime represented a strong disruption for the cooperative movement in all four countries. As a result, negative social connotations are still associated with cooperatives in the general public, and they hinder the revitalisation of the cooperative sector. 


\section{Ciepielewska-Kowalik, Vidović, Kiss et al.}

\subsection{Convergences and Divergences}

The most striking convergences among the four studied countries relate to exogenous factors, primarily linked to EU integration processes. There is no doubt that accession to the EU was a key stimulus that has shaped social enterprises' development path in all the countries considered. In particular, EU policies constitute key factors that have fostered-and continue doing so-SE institutionalisation by supporting these enterprises' recognition and the development of their ecosystem. The impact of the EU is particularly obvious in increasing recognition of and political attention for social enterprise, as clearly appears from the analysis of all the countries studied. This is seen in the intensive production of strategies, legislation and policies that has been occurring during the last decade and a half. Furthermore, in all four countries considered, social cooperatives emerged as a new legal type whose evolution is particularly influenced by EU policies.

Other convergences among the four countries are rather linked to internal factors. First, the SE sector in these countries is still in a very early stage of development, partly because the "birth place" of social enterprises in these countries is in most cases the non-profit sector, which is traditionally not particularly focused on economic performance. However, in all post-transition societies, structural reforms have not been fully completed yet, and there are still gaps in state provision of welfare programmes and unaddressed social needs; as a result, there is a space and need for social enterprises to get involved.

A second point of convergence lies in the fact that the introduction of SE policy frameworks in all the countries analysed was shaped by a top-down approach, which often resulted in a serious gap between the criteria put forward to define social enterprise at the administrative (and political) level(s), on the one hand, and actual practices, on the other hand. This is particularly visible in the cases of Poland and Croatia, where the requirements defined in policy documents have proven unrealistic, and their application impossible. There are many examples hereof, such as the legal act regulating social cooperatives in Poland. According to its first version, enacted in 2006, all persons who planned to establish a social cooperative had to belong to one of the vulnerable groups identified in other legal acts. This made the process of establishing and running a social cooperative almost impossible if the founders were not supported by external actors. This unfavourable regulation was gradually changed in the years 2007-2018, though, by widening the list of vulnerable groups and permitting persons who are not threatened by social exclusion to establish a social cooperative (provided the persons who are not at risk of social exclusion do not represent more than $50 \%$ of the founders). Still, overall, it can be considered that policy frameworks did not manage to create a fully supportive environment for SE development. 
The four countries analysed also converge on another aspect-namely the fact that there is still confusion about the concept of social enterprise. One of the main topics of the policy discourse on social enterprise is employment (of vulnerable social groups); as a result, the role of social enterprise in job creation is becoming notably more visible and gaining importance, but such development also threatens to narrow the understanding of social enterprise and to exclude all the social enterprises that do not have employment as their main purpose. This situation often results in the exclusion of some organisations from mapping and registration and/or from access to public funds.

Finally, the SE sector operates, in the four countries under consideration, in a strongly isomorphic manner, as the situation in the sector is impacted by pressures from the state and other funding entities. This is due to the fact that most of the social enterprises operate mainly within projectoriented schemes and largely rely on public-often EU-co-financedfunds. This results in turn in a certain weakness of the sector, which is characterised by unsustainability and serious fluctuations of SE actors.

Beside these convergences, there are also important differences between the countries that belonged to the Eastern, or post-Soviet bloc (Poland, Hungary and the Czech Republic), on the one side, and the country that was part of Yugoslavia (Croatia), on the other side. We may assume that the main line of divergence can be related to the different types of socialism that existed in these two blocs, and which created quite different conditions for the democratic transition.

"Soviet-type" socialism, known as state socialism (or ideologically marked as "real" socialism), more severely curtailed human rights and freedoms. During decades, this created accumulated dissatisfaction and resistance, which were finally articulated in the democratic transitions that started in the late 1980s. These bottom-up movements of people led to the collapse of the communist regime, and at least partly enabled a change of political elites.

On the other side, "Yugoslavian-type" socialism was based on selfmanagement and was largely marked by more liberal tendencies. This somehow "softer" socialist regime gave more freedom to people and can be assumed to have resulted in less intensive resistance. Also, the national issues, in the multi-ethnic context of Yugoslavia, intensified in the early 1980s and shifted the main conflict line from anti-communism to nationalism. The "democratic" transition in post-Yugoslavia was led by parts of the former (communist) political elite and was accompanied by the breakdown of the Yugoslavian federation, a process of nationstate building and ethnical conflicts and wars. This top-down transition (Kasapović 1996) did not lead to a factual change of political elites, and democratic tendencies were put aside for a decade.

Stronger democratic tendencies only emerged, in a majority of countries from the former Yugoslavia, from the beginning of the 2000s onwards; 


\section{Ciepielewska-Kowalik, Vidović, Kiss et al.}

they were then followed by the EU integration processes. This decade of "delay", as compared to the countries of the former Eastern Bloc, can best be observed in the dynamics of EU membership: EU accession processes began, for countries from the former Yugoslavia (apart from Slovenia), almost a decade later than in post-Soviet countries-Poland, the Czech Republic and Hungary became EU members in 2004; Croatia, in 2013. This late democratisation of countries of the former Yugoslavia has influenced the current state of the SE field and caused delayed processes of SE development in those countries. However, both types of societies still experience a "democratic deficit" and are still characterised by strong authoritarian tendencies, which are a constant threat to democracy and consequently to the development of social enterprise.

\section{Conclusion}

Though initially a Western concept, the emerging SE sector has in recent years attracted increasing attention from policymakers, development experts and researchers in CEE countries as well. However, as our analysis shows, the SE sector has important characteristics specific to this region, which stem from its historical development and current circumstances. Thus, when discussing the state of SE development in post-socialist countries, a look back at the historical background gives some valuable insights into current trends and influences. In our analysis, we refused snap interpretations that see the (democratic) transition as a clear cut from the "socialist darkness", as we find it more useful and accurate to recognise and emphasise all the elements that are relevant for a better understanding of SE development - that is, not only the elements of discontinuity but also the main elements of continuity between the pre-socialist, socialist and post-socialist periods.

The analysis in this chapter opens the field for future research on social enterprises in post-socialist societies that would consider the specificities of these societies and accordingly better understand the different paths of SE development.

\section{Acknowledgements}

Anna Ciepielewska-Kowalik declares that the analysis regarding Poland in based on research financed by the National Science Centre Poland, within the framework of the project titled Co-production of welfare services: Education and social assistance policy in Poland after 1989 (No. 2015/19/D/HS5/00514).

\section{Notes}

1. Namely the Ministry of Family, Labour and Social Policy, and in particular the Department of Public Benefit in Poland; the Government Council for 
Non-Governmental Organisations in the Czech Republic; the Ministry for National Economy, the Ministry of Finance and the Ministry of Interior in Hungary; the Ministry of Labour and the Pension System, the Ministry of Economy and Sustainable Development, the Ministry for Demography, Family, Youth and Social Policy, and the National Foundation for Civil-Society Development in Croatia.

2. "Entrepreneurial non-profit organisation" (ENPO) is not a legal form but an analytical term, which we use for foundations, associations and similar social organisations carrying out economic activities.

3. In Hungary, the number of social cooperatives rose from 349 in 2012 to 2,980 in 2016 (see European Commission 2019b).

\section{References}

Bartal, A. M. (2005) Nonprofit elméletek, modellek, trendek, Budapest: Századvég Kiadó.

Bényei, A., Bíró, E., Kinyik, M., Nagy, Á., Nizák, P. \& Péterfi, F. (2007) “A kormányzat civil stratégiája és az ehhez füzött civil szakmai álláspont”, Civil Szemle, Vol. 4, No. 2, pp. 5-54.

Bocz, J. (2009) A non-profit szektor strukturális átalakulása Magyarországon. A magyar non-profit szektor az 1990-es évek elejétól a 2000-es évek közepéig, PhD thesis, Budapest: Budapesti Corvinus Egyetem, Szociológiai Doktori Iskola.

Ciepielewska-Kowalik, A. (2015) "Public policy on social enterprises in Poland: The impact of tradition and transition", Studia Polityczne, Vol. 38, No. 2, pp. 75-97.

Cioch, H. (2011) Prawo spótdzielcze, Warsaw: Wolters Kluwers.

CIVICUS (1997) The New Civic Atlas: Profiles of Civil Society in 60 Countries, Washington, DC: CIVICUS.

Dohnalová, M. (2013) Sociálni ekonomika, sociální podnikání. Podnikání pro každého, Prague: Wolters Kluwer ČR.

Dohnalová, M., Deverová, L., Legnerová, K. \&Pospíšilová, T. (2016) Lidskézdroje v sociálníchpodnicích, Prague: Wolters Kluwer.

European Commission (2016) Mapping study on Social Enterprises Ecosystems-Updated Country report on Poland (Authors: Ciepielewska-Kowalik, A. \& Pieliński, B.), Brussels: European Commission, Directorate-General for Employment, Social Affairs and Inclusion.

European Commission (2019a) Social Enterprises and Their Ecosystems in Europe. Updated Country Report: Croatia (Author: Vidović, D.), Luxembourg: Publications Office of the European Union. Available HTTP: www. euricse.eu/social-enterprises-and-their-ecosystems-in-europe-mapping-study/.

European Commission (2019b) Social Enterprises and Their Ecosystems in Europe. Updated Country Report: Hungary (Authors: Kiss, J. \& Mihály, M.), Luxembourg: Publications Office of the European Union. Available HTTP: www. euricse.eu/social-enterprises-and-their-ecosystems-in-europe-mapping-study/.

European Commission (2020) Social Enterprises and Their Ecosystems in Europe. Updated Country Report: Poland (Author: Ciepielewska-Kowalik, A.), Luxembourg: Publications Office of the European Union. Available HTTP: https://ec.europa.eu/social/main.jsp? pager.offset=5\&advSearchKey=socnteco 


\section{Ciepielewska-Kowalik, Vidović, Kiss et al.}

$\&$ mode $=$ advancedSubmit $\&$ catId $=22 \&$ doc $\_$submit $=\&$ policyArea $=0 \&$ policyAr eaSub $=0 \&$ country $=0$ \&year $=0$.

Frič, P., Goulli, R., Toepler, S. \& Salamon, L. M. (1999) “The Czech Republic”, in Salamon, L. M., Anheier, H. K., List, R., Toepler, S., Sokolowski, S. W. \& Associates (eds) Global Civil Society. Dimensions of the Nonprofit Sector, Baltimore, MD: The Johns Hopkins Center for Civil Society Studies.

G. Fekete, E., Hubai, L., Kiss, J. \& Mihály, M. (2017) "Social enterprise in Hungary", ICSEM Working Papers, No. 47, Liege: The International Comparative Social Enterprise Models (ICSEM) Project.

Government of the Republic of Croatia (2006) National Strategy for the Creation of an Enabling Environment for Civil Society Development 2006-2011, Zagreb: Government of the Republic of Croatia.

Hunčová, M. (2004) "The Czech co-operative reality and its social aspects", in Borzaga, C. \& Spear, R. (eds) Trends and Challenges for Co-operatives and Social Enterprises in Developed and Transition Countries, Trento: EDIZIONI31.

Kasapović, M. (1996) "Demokratska tranzicija i političke institucije u Hrvatskoj”, Politička misao, Vol. 33, No. 2-3, pp. 84-99.

Kovách, I. (2012) A vidék az ezredfordulón. A jelenkori magyar vidéki társadalom szerkezetiés hatalmi változásai, Budapest: Argumentum; MTA Társadalomtudományi Kutatóközpont (Szociológiai Intézet).

Leś, E. (2001) Zarys historii dobroczynności i filantropii w Polsce, Warsaw: Prószyński i S-ka.

Leś, E. (2004) "Cooperatives in Poland: From state-controlled institutions to new trends in cooperative development", in Borzaga, C. \& Spear, R. (eds) Trends and Challenges for Co-operatives and Social Enterprises in Developed and Transition Countries, Trento: EDIZIONI31.

Leś, E., Nałęcz, S., Wygnański, J. J., Toepler, S. \& Salamon, L. M. (1999) "Poland", in Salamon, L. M., Anheier, H. K., List, R., Topeler, S., Sokolowski, S. W. \& Associates (eds) Global Civil Society. Dimensions of the Nonprofit Sector, Baltimore, MD: The Johns Hopkins University, pp. 325-35.

Mansfeldová, Z., Nałęcz, S., Piller, E. \& Zimmer, A. (2004) "Civil society in transition. Civic engagement and nonprofit organizations in central and Eastern Europe after 1989", in Zimmer, A. \& Piller, E. (eds) Future of Civil Society. Making Central European Nonprofit Organizations Work, Wiesbaden: VS Verlag für Sozialwissenschaften.

Nadace Neziskovky.cz (2018) Statistika počtu nestátních neziskových organizací 2014-2017. Available HTTP: www.neziskovky.cz/clanky/511_695/fakta_ statistika-postu-nno/.

Nagy, R. \& Nizák, P. (2009) “A civil szektor pénzügyi életképessége, források, pályázati rendszer”, Civil Szemle, Vol. 6, No. 1-2, pp. 35-58.

Pejnović, D., Radeljak-Kaufmann, P. \& Lukić, A. (2016) "Razvoj i suvremena obilježja poljoprivrednoga zadrugarstva na prostoru Hrvatske”, Hrvatski geografski glasnik, Vol. 78, No. 2, pp. 5-48.

Singer, S. \& Lauc, B. (2004) Razvoj sektora malih i srednjih poduzeća: Hrvatska, Support to Promotion of Reciprocal Understanding of Relations and Dialogue between the European Union and the Western Balkans. Available HTTP: www. yumpu.com/xx/document/read/7324184/razvoj-sektora-malih-i-srednjihpoduzeca-hrvatska-w estern-. 
Štulhofer, A. (2004) "Percepcija korupcije i erozija društvenog kapitala u Hrvatskoj 1995-2003", Politička misao, Vol. 41, No. 3, pp. 156-69.

Vidović, D. (2012) Socijalno poduzetništvo u Hrvatskoj, PhD thesis, Zagreb: Faculty of Humanities and Social Sciences University of Zagreb.

Vidović, D. \& Rakin, D. (2017) "Social entrepreneurship and the revitalization of the cooperative sector: Emergence of social cooperatives in Croatia and Serbia”, in Baglioni, S., Roy, M., Mazzei, M., Srbijanko, J. \& Bashevska, M. (eds) Social Enterprise Developments in the Balkans, Joint Volume by the Balkan Social Enterprise Research Network, Skopje: Reactor-Research in Action, pp. 7-22.

Žimbrek, T. (2008) Agrarna politika, izabrana predavanja, Zagreb: vlastita naklada. Available HTTP: bib.irb.hr/462548.

Zrinščak, S. (2008) “Obiteljska politika”, in Puljiz, V., Bežovan, G., Matković, T, Šućur, Z. \& Zrinščak, S. (eds) Socijalna politika Hrvatske, Zagreb: Pravni fakultet, pp. 279-336. 